\title{
Temporal skin folds in a female infant with an unbalanced translocation with breakpoints Xq22.1 and 6p22.3: a new association?
}

\author{
G T Vasileiadis, ${ }^{1}$ N Fordham, ${ }^{1}$ M Augustynowicz, ${ }^{2}$ R H Scott ${ }^{3}$
}

'Department of Neonatology, BHR University Hospitals NHS Trust, London, UK

${ }^{2}$ Department of Cytogenetics, North East Thames Regional Genetics Service, London, UK ${ }^{3}$ Department of Clinical Genetics, North East Thames Regional Genetics Service, London, UK

\section{Correspondence to} Dr GT Vasileiadis, George.Vasileiadis@ bhrhospitals.nhs.uk
To cite: Vasileiadis GT, Fordham N,

Augustynowicz $\mathrm{M}$, et al. BMJ Case Rep Published online: [please include Day Month Year] doi:10.1136/ bcr-2013-010352

\section{DESCRIPTION}

A female infant was born to healthy unrelated parents with no relevant family history. She had normal antenatal scans and was born by spontaneous vaginal delivery at 33 weeks' postmenstrual age. She was admitted to the neonatal unit for prematurity and respiratory distress. She was noted to have marked bilateral and dysplastic skin folds on her temples (figures 1 and 2) but no other dysmorphic features.

Array comparative genomic hybridisation and subsequent fluorescence in situ hybridisation detected an unbalanced $\mathrm{X}$ autosome translocation resulting in $53 \mathrm{Mb}$ deletion at Xq22.1q28 and $17.5 \mathrm{Mb}$ duplication at $6 \mathrm{p} 22.3 \mathrm{p} 22.3$. Both parents had normal karyotypes indicating that the translocation had arisen de novo. Thyroid function tests, structural/functional echocardiography, cranial and renal ultrasound scans and ophthalmological examination were normal. Hearing test was also within normal results.

At the age of 14.5 months neurodevelopmental assessment (Bayley III) was performed. ${ }^{1}$ After adjustment for prematurity, the performance was within the expectations for age: Cognitive Composite Score 85 (percentile rank 16), Language Composite Score 103 (percentile rank 58) and Motor Composite Score 103 (percentile rank 58). Neurological examination was normal and there were no clinical concerns.

The translocation did not have exact precedent in the medical literature. As with other X autosome translocations in females, its phenotypic impact may be ameliorated by non-random $\mathrm{X}$ inactivation.

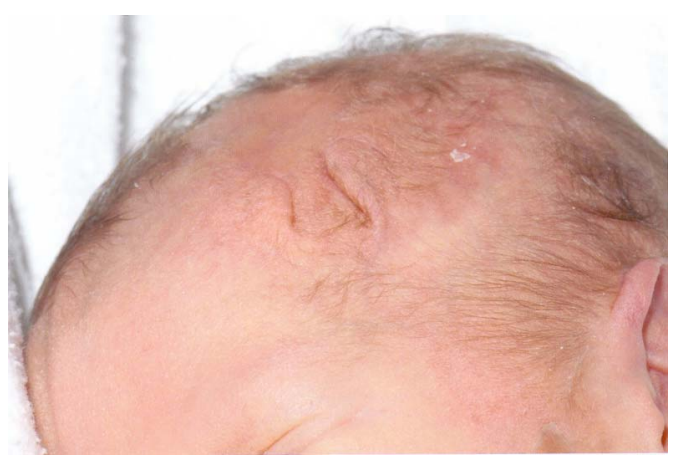

Figure 1 Left temporal skin folds.

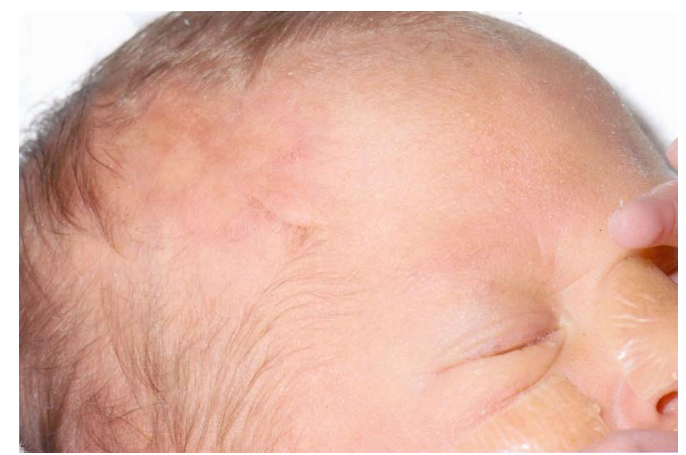

Figure 2 Right temporal skin folds.

A small number of individuals have been reported with similar focal facial dermal dysplasias such as Setleis syndrome. ${ }^{2}$ The case does not establish a causal relationship, but reports a possible new association between this translocation and temporal skin folds.

\section{Learning points}

- We report a child with bilateral temporal skin folds and with an unbalanced translocation with breakpoints at Xq22.1 and 6p22.3, a possible novel association.

- Unbalanced translocation with breakpoints at Xq22.1 and 6p22.3 is not associated with impaired early neurodevelopmental outcome.

- Array comparative genomic hybridisation is the first line investigation for the detection of unbalanced chromosome translocations.

Competing interests None.

Patient consent Obtained.

Provenance and peer review Not commissioned; externally peer reviewed.

\section{REFERENCES}

1 Bayley N. Bayley scales of infant and toddler development-ll. San Antonio, Texas: The Phychological Corporation, 2006.

2 Garcia-Minaur S, Linares A. Setleis ("bitemporal forceps marks") syndrome. Clin Dysmorphol 1995:4:173-5. 


\section{Images in...}

Copyright 2013 BMJ Publishing Group. All rights reserved. For permission to reuse any of this content visit http://group.bmj.com/group/rights-licensing/permissions.

BMJ Case Report Fellows may re-use this article for personal use and teaching without any further permission.

Become a Fellow of BMJ Case Reports today and you can:

- Submit as many cases as you like

- Enjoy fast sympathetic peer review and rapid publication of accepted articles

- Access all the published articles

- Re-use any of the published material for personal use and teaching without further permission

For information on Institutional Fellowships contact consortiasales@bmjgroup.com

Visit casereports.bmj.com for more articles like this and to become a Fellow 